\title{
Political leadership and 'non-traditional' development cooperation
}

\author{
Abstract \\ This article explores the relationships between (so-called) 'non-traditional' \\ development cooperation (NTDC) and political leadership. Using the case studies of \\ Brazil and South Korea, we propose that certain emblematic elements of NTDC \\ discourse and practice can act to influence the relationship with political leaders in \\ particular ways. These are (a) elevated language of affect, (b) interleaving of \\ personal biographies with the developmental trajectories of states, (c) the use of \\ NTDC to legitimise domestic policies and promote domestic political leadership, (d) \\ the prominence of presidential diplomacy, and (e) the challenges confronting \\ rapidly expanding domestic development cooperation institutions and systems.
}

\section{Key words}

Non-traditional development cooperation; South-South Development Cooperation; political leadership; development; South Korea; Brazil

\section{Acknowledgements}

We are grateful to the editor and anonymous referees of Third World Quarterly for their reviews and suggestions for this paper. The paper was delivered at the international workshop "Looking ahead: South-South development cooperation in the next decade", which was supported by the UK's Development Studies Association (Rising Powers Study Group), in Cambridge on 26 May 2015. We are grateful to other participants for their comments and constructive critique.

\section{Introduction}

Over the last 10-15 years, a growing number of states have launched or expanded roles in humanitarian assistance, technical cooperation and development finance, often in concert with broader diplomatic, trade and investment agendas. ${ }^{1}$ Together with other 'new' development actors such as foundations and a much stronger role for the private sector, the outcome has been a far more heterogeneous and polycentric development landscape. ${ }^{2}$ So-called 'non-traditional' partners ${ }^{3}$ are asserting a stronger stance within global development institutions in terms of dialogue and collaboration, or indeed, by 
choosing to hold them at arm's length. ${ }^{4}$ Southern partners in particular have very successfully projected apparent ideational alternatives to some aspects of mainstream development languages, practices and ideologies; ${ }^{5}$ albeit not in ways that are contesting the evolving injustices of neoliberal globalisation. ${ }^{6}$ These changes present stimulating theoretical challenges to analysts of international development. In this paper we contribute to this burgeoning literature through a novel exploration of the relationships between political leadership and emerging/expanding involvement with development cooperation. While much has been written on the institutional, bureaucratic and legal structures of different non-traditional partners, assessments of particular political leaders have generally been individualised within specific country case studies. ${ }^{7}$ In this paper we seek to complement these studies by identifying broader characteristics of discourse and practice that potentially interplay with the ways in which political leaders assert their roles and identities in the context of rapidly evolving/expanding development cooperation.

The paper sets out five loosely shared characteristics of NTDC that can act to shape the context for political leaders in particular ways. These are (a) the elevated language of affect, (b) the interleaving of personal biographies with the developmental trajectories of states, (c) the use of NTDC to legitimise domestic policies and promote domestic political leadership, (d) the particular prominence of presidential diplomacy, and (e) the challenges confronting rapidly expanding domestic development cooperation institutions and systems. We do not wish to over-state the case: other domestic and international factors intervene, and specific circumstances and contexts are extremely important. Even so, we propose that this broader conceptual analysis of the relationship provides some novel insight into shifts in terrain of international development.

To explore these ideas in more detail we present two short case studies - South Korea (hereafter Korea) and Brazil. While Brazil is generally situated as a major 'Southern' actor and thus (in the unsatisfactory designation) 'non-traditional', Korea has long disconcerted simple hierarchies and spatialised rendering of 'developing/Southern' and 'developed/Northern' countries. ${ }^{8}$ Notwithstanding its post-2010 DAC membership, many analysts point to an identity, narrative and set of modalities that more closely resemble those of other Asian and indeed Southern partners. In our view, Korea's DAC membership alone does not place it with the category of 'Northern' or (so-called) 'established' donors, in terms of ongoing domestic debates with regard to competing aid policy priorities, future visions, and self-positioning as a major recipient turned donor. ${ }^{9}$ 
Korea's emphasis on the 'win-win' partnership, its development policy experience and the commercial profile of its aid programme (e.g. relatively high tied-aid ratio and its prevalent use of loans as an aid instrument) are similar to the practices of Japan and China. ${ }^{10}$ So we use 'non-traditional' here to include the overlapping category of Asian donors and development partners. All such categories entail problematic slippages, but we hope to show below that the pairing of Brazil and Korea is analytically useful. The paper does not provide comprehensive accounts of Brazilian or Korean development cooperation, but in each case focuses on the relationship between two successive recent presidents and their international development approaches and strategies. In both cases there has been a transition of leadership within the same party - the conservative Saenuri Party in Korea, and the Partido dos Trabalhadores (Worker's Party) in Brazil. Interestingly, the substantial differences between Korea and Brazil actually work to highlight surprising similarities in the narratives and practices, and the foregrounding of the role/impact of specific political leaders. ${ }^{11}$

The aim of the paper is not to argue that political leaders are always and everywhere the primary drivers or architects of NTDC policies and practices; or to the extent that there are shared NTDC characteristics, to propose that they determine leadership agendas and approaches. Clearly, in all cases there are multiple domestic and external actors, institutions and factors that debate and shape NTDC, from overarching policies through to specific programmes and interventions. By the same token, Brazilian and Korean narratives and practices are not monolithic - like all development actors, they embody and voice complexity and plurality. With these caveats in place, we propose that some of the underlying characteristics of NTDC set up particular 'frames' for political leaders.

\section{Framing political leadership in NTDC}

Within the field of Political Science and International Relations, there have been attempts to assess the influence of political leadership in foreign policy outcomes, including in situations of foreign policy change. Although this literature recognizes their importance in signaling the relevance of factors such as the personality of political leaders, ${ }^{12}$ we have different objectives in this paper and we do not share the methodological approaches and tools employed in these contributions. Our aim is to examine the ways in which widely shared tropes of non-traditional development cooperation relate to particular projections of and roles for political leadership. Our argument is in line with recent contributions that highlight the influence of political 
leadership (particularly of the head of the Executive power) in enacting innovation in foreign policy. ${ }^{13}$

To date, although there has been considerable research into the domestic politics and institutions of NTDC, including the role of individual leaders, political leadership has not been subject to a broader conceptual framing. There is good reason for this: analysts must be attentive to the differences in the capacities of different partners, and to the very substantial variation in their histories, agendas, languages and interests. The gaps between high level statements and their translation down to more complex ground realities also need to be noted and addressed. ${ }^{14}$ Even so, some commentators suggest that it is possible to trace a core of ideas and approaches that are distinctively claimed, articulated and practiced by NTDC partners. ${ }^{15}$ These include a narrative frame historically anchored in a Third World-ist and Non-Aligned Movement insistence on sovereign autonomy, international political justice and solidarity; an assertion of development expertise based on direct experience; and a holistic conception of development financing and activity, in which aid policies and programmes are positively blurred and blended with trade, investment and diplomacy. At the same time, most NTDC partners are working to expand their economic and diplomatic interests in ways that, unlike earlier eras, do not offer an ideational contest to the dominant regime of neoliberal globalization (rather, they are imbricated in the current deepening of statecapital hybridity). ${ }^{16}$ Within this context, the following framework sets up five ways in which these loosely shared discourses and practices of NTDC may shape the agency and conduct of individual political leadership. We set these out in the abstract first, and then explore them in terms of the two case studies in the following sections.

First, in speeches and texts, NTDC is very often framed in language that elevates affect that is, sensibilities and emotions. The discourse of NTDC partnership projects an empathetic connection between states that share colonial and post-colonial histories of subjugation, as well as in some cases, linguistic and cultural affinities. ${ }^{17}$ Political leaders therefore have at their disposal an attractive and resonant set of discursive resources in which they can represent themselves as champions of solidarity, justice, growth and mutual benefit. NTDC is framed by powerful moral claims, with variation inflected through specific country histories, cultures and circumstances and frequent recourse to expressions of feeling - pain, warmth, empathy and so on. As we will see, NTDC-related statecraft is often highly personalised through the language and performance of affect. 
This has a bearing on the second element of the framework, which is that most of the present generation of presidents and prime ministers in the South have themselves lived through national transitions, from being only or primarily recipients, and in some cases experiencing considerable poverty, to becoming more visible and active development partners. While individual circumstances are diverse, we find that this personal experience anchored within a national trajectory can enable explicit parallels to be constructed between the personal biography and experiences of an individual leader and NTDC discourses and practices.

Third, NTDC is often strongly based around assertions of 'successful' development experiences implemented domestically. The role of political leadership can become important where those leaders have been involved in the launch and roll-out of these policies, and are therefore politically invested spokespersons for the 'transfer' or 'export' of these policies within and beyond the global South. The experience of providing NTDC can serve the purpose of legitimising certain policies and leaders at both the domestic and international levels.

Fourth, the history and contemporary practices and performances of NTDC are strongly associated with presidential/prime ministerial diplomacy at high-level meetings. The origins of NTDC are primarily located in attempts to assert Third World sovereignty and autonomous decision making, advanced by Nehru, Sukarno, Nkrumah, Castro and many others. Through events like the Bandung Conference (1955), the Tricontinental Conference (1966), and the Non-Aligned Movement (launched in 1961), Third World and other leaders contested their uneven insertion into post-colonial geopolitics and world economy.18 Development cooperation - the expression of solidarity and exchange of technical assistance, goods and finances - played a part in this. The history of NTDC is of course also one of subaltern agents, from Vietnamese technical cooperation personnel ${ }^{19}$ to Chinese engineers and labourers on the Tanzam railway, ${ }^{20}$ something that remains the case today. ${ }^{21}$ Historically though, the energy behind NTDC has been primarily generated from above, with highly visible displays of state-state conviviality, personalised in high-level summitry. These include the BRICS Forum, the India-Africa Forum Summit, and the China-Africa Forum. ${ }^{22}$ These and other meetings have become key settings for apex leaders to convey their political messages and to build up alliances with like-minded political peers. They are high profile stages for leaders to assert new and growing solidarities, often pictured (literally) in terms of leaders shaking hands, giving speeches, and sharing platforms. This individualised presidential prominence 
sometimes outpaces NTDC institutionalisation, which leads on to the next part of the framework.

The final characteristic of NTDC with implications for the role of political leadership is that in most (so-called) 'non-traditional' partner countries, development cooperation institutions tend to be less consolidated or powerful than other parts of their foreign policy structures and capacities. Typically, analysts point to fragmented and sometimes competing internal structures, and generally low levels of personnel and human resources. This results in limited capacities to set policy, disburse funds, monitor programmes, or take part in regional and international development forums on even terms with the more 'established' donors. Given the rapid expansion of NTDC, its blurred and blended nature, and the changing contexts of the 21st century, this is hardly surprising, and many NTDC partners are currently rationalising and expanding their development cooperation infrastructures. ${ }^{23}$ To date though, most have relatively limited institutional strength, which potentially enable a stronger role for apex political leaders in setting the tone and agenda for NTDC.

In the next section of the paper we turn to Korea and then Brazil to examine these ideas in relation to particular contexts and people. For obvious reasons, these are not simple equivalents - we find more evidence for some of our proposed relationships in one and not the other. We would expect this to be the case in extending these arguments to other non-traditional development partners.

\section{Korea}

Korea has grown from one of the world's poorest aid recipient countries in the 1950s into one of the world's largest economies. In 2010 Korea became only the second nonWestern member of the OECD-DAC (the other being Japan), a striking demonstration of its transformation. Korea has since been active in projecting an international image as a respected diplomatic bridging agent, and provider of development knowledge based on its experience of rapid economic growth. ${ }^{24}$ Korea's net ODA provision expanded more than eight-fold from the turn of the century to USD 1.9 billion ( 0.14 percent of GNI) in 2015.25 Its emergence in global aid politics and development debates is also highlighted in its hosting of various high-level aid talks, notably the 2010 G20 Summit in Seoul and the 2011 Fourth OECD High-Level Forum on Aid Effectiveness in Busan. ${ }^{26}$ Notwithstanding its DAC accession in 2010, active diplomatic presence and growing aid 
profile, Korea still has many attributes and approaches that are associated with other South-South/Asian development partners. Derived from its identity as a former recipient, these support Korea's claims to empathy and expertise, and in assetising its 'emerging middle power' status, bridging between rich and poor countries. ${ }^{27}$ In this section we examine the five characteristics of NTDC activities identified earlier in relation to the presidencies of Lee Myung-bak (2008-13) and Park Geun-hye (20132017). ${ }^{28}$

The first two premises - the elevated language of affect and the personalization of national development history - are pronounced aspects of Korean aid discourse. Korea's remarkable development trajectory provides a dramatic backdrop for the invocation of leaders' personal stories. Both presidents have lived through the country's rapid, recent development history, and their personal and professional biographies interweave with this national transformation. The experience of poverty and hunger in the aftermath of the Korean War (1950-53) remains in public memory, as well as the pains and triumphs of rapid economic development during the authoritarian developmental decades of the 1960s to the 1980s. For instance, in 2012 President Lee Myung-bak delivered a speech at the reception for the second board meeting of the Green Climate Fund to secure the Fund's permanent headquarters in Songdo, Korea, blending first and third person narratives:

When I was a primary school kid, there was an American missionary, who used to clean old clothes and bring them in a large box to distribute to us. I would also queue up to receive a pair of used trousers. The small boy that queued up for the used trousers became a president. And he wants to offer aid to the countries where poor boys and girls like him are many, and declare his country has transformed from an aid recipient into a donor. This is not only a meaningful reward for me personally but I think it is the pride of all our [Korean] people, who had to undergo such difficult times in the past ... As we know better than any others how aid-receiving people feel, we want to help them out in earnest. (President Lee, 17 October 2012)29

By personalising the nation's development trajectory in resemblance of his own history, the president projected himself as an epitome of the nation's modern suffering and achievement. He could justifiably assert an empathetic connection to the poverty of others, but also invoke hope and aspiration through his own story of success. Needless 
to say, what parts of the past are 'remembered' and how these are narrativised are malleable. In fact Korea's ambiguous Northern/Southern identity is based on the transformation story, which contrasts its 'Southern' past with its present status of becoming an 'official' donor/DAC member. While traditional Northern donors seldom emphasise their commonality with recipients, Korea's aid rhetoric heavily draws upon its own recipient experience. It blends with national pride, which is expressed, for instance, in the self-image as an effective and compassionate donor which does the job differently from - and arguably better than - traditional Northern donors.

Supporting the third premise, these personalized and affective development narratives can also be invoked to help legitimise leaders' domestic policy choices and political influence. Korea's foreign aid programmes have been explicitly subject to the particular policy preferences of presidents, reflecting the personal and political imperatives of the top leadership. For example, President Lee Myung-bak placed significant emphasis on infrastructure development and the 'Green Growth' development initiative, while the Park Geun-hye government projected very strongly the Global Saemaul movement. ${ }^{30}$ The external promotion of these initiatives can be seen in part as being designed to enhance the political standing of their particular advocates at home as well. For instance, President Lee was a former CEO of Hyundai Construction and Engineering, and a strong believer in economic growth spurred by investment in economic infrastructure. ${ }^{31}$ It was widely known that President Lee was personally interested and deeply engaged in the discursive push to mainstream economic growth and knowledge sharing initiatives at the G20 Seoul Development Consensus in 2010.32 This in turn fed into the global momentum behind the policy shift from 'aid effectiveness' to 'development effectiveness', which emphasizes the role of development finance and the private sector in boosting productive bases of economic growth.$^{33}$ Connecting to the policy emphasis on infrastructure development, President Lee also pushed the idea of Green Growth, making 'Green ODA' a key part of the government promotion of Global Korea. President Lee Myung-bak put his personal legacy and the country's reputation on the line with its global leadership' under his administration's overarching 'Global Korea' agenda, ${ }^{34}$ and ODA was one means to realize that aspiration. ${ }^{35}$ The Global Green Growth Institute was established, and the Green Growth Fund headquartered in Korea with an ambition to make Korea the hub of Green Growth knowledge sharing and policy experimentation. ${ }^{36}$ The East Asia Climate Partnership (EACP) was also established to facilitate the spread of renewable energy technologies and power plants as part of Korean aid to Asian recipient countries, with an aim to increasing Green ODA to take up to 30 percent of 
total Korean aid projects. ${ }^{37}$ It is important to note that the concept of 'Green Growth' and its related projects were domestically contested. For example, through the Four Major Rivers Project, rivers were 'refurbished' as the government set out the goals of increasing their water storage capacity, mitigating risks of floods and water shortage, and ensuring 'eco-friendly' water management. The plan was carried out by the Lee government in 2008 despite considerable domestic controversy: environmental CSOs and experts feared ecological damage, while political skeptics thought that construction companies involved were receiving policy favors for their ties with the president's business career. ${ }^{38}$ The international spread and presence of Korea's 'Green Growth' agenda as part of ODA package arguably helped legitimate its domestic roll out.

However, following the end of the Lee government, the 'Green Growth' agenda was sidelined under President Park Geun-hye. Instead, the former Park government sought to project 'Global Saemaul Movement' (or Global Saemaul Undong) as Korea's distinctive contribution to international development. Opposition politicians accused the government of using public (aid) money to the president's own political benefit by commemorating and glorifying her father's developmental achievements. ${ }^{39}$ The original Saemaul Movement was initiated in the 1970s as a rural development project inspired and closely supervised by then President Park Chung-hee (1961-1979), a highly controversial leader who spearheaded the nation's authoritarian developmental state, and President Park Geun-hye's father. President Park Geun-hye has frequently evoked the nation's 'miraculous' industrialization and the 'success' of Saemaul Movement in the 1960s and 1970s, drawing on her father's economic legacy in a way to boost her domestic popularity. KOICA-led efforts to globalise the Saemaul Movement in its ODA programmes include inviting recipient government officials and civilians to Korea to immerse them in the hopeful 'can-do' spirit of Saemaul Movement. ${ }^{40}$ Political sensitivities persist over the present government's promotion of Saemaul Movement as a major policy driver for Korean ODA, ${ }^{41}$ with critics remaining sceptical about its earlier motivations as well as its current revival. ${ }^{42}$

The fourth and fifth observations (presidential diplomacy and institutional limitations) also apply to the Korean case. Notwithstanding Korea's growing wealth and OECD-DAC member status, a number of commentators suggest that its aid and development infrastructure does not fully reflect its international commitments and ambitions. ${ }^{43}$ In part, this is seen as a result of inter-ministerial competition between the government's two main channels of ODA loans (by the Finance Ministry) and grants (by the Foreign 
Ministry) in spite of institutional mechanisms to harmonize the two flows. ${ }^{44}$ Similar to other NTDC providers (and indeed some DAC donors), Korea's international development institutions can be regarded as fragmented compared to other parts of its foreign policy apparatus and capacities. ${ }^{45}$ Analysts have suggested that this is one reason why elite political influence is particularly prominent in shaping Korea's key policy decisions in its ODA programme, reflecting the motivations and ideological orientations of the top political leadership under the highly centralized presidential system in Korea. The country's five-year presidential system, limited to a single-term in office, means that certain ODA policy catchphrases are often short-lived, lacking longerterm consistency and vulnerable to power transition in political leadership. For instance, President Lee's pledge - proclaimed in Busan HLF-4 - to increase the country's ODA volume to 0.25 percent of GNI by 2015 has not been fulfilled under the Park government, and there is no internal accountability mechanism across the presidencies. Excessive reliance on the preferences and will of top political leaders may undermine the stability and predictability in Korean ODA policy.

Analyses of Korea's growing profile as an international development partner demonstrate the ways in which individual presidents have - to some extent - shaped particular narratives, initiatives and programmes. Successive presidents have asserted their influence over the content of ODA programmes to further domestic political support, as well as to raise Korea's standing internationally. The wider characteristics of NTDC enable and even encourage the projection of individual leaders in ways that blend the personal and professional. Korea demonstrates, for example, the affective opportunity offered to leaders of 'non-traditional' partner states. President Lee, in particular, was able to deploy his personal biography to powerful effect in global meetings - a claim to empathy which has less traction in other areas of Korean foreign policy, and which is denied to Western leaders in their donor narratives. To explore these arguments further, we turn now to the very different example of Brazil.

\section{Brazil}

The analysis of the Brazilian case focuses on the period between 2003 and 2016, which covers the transition from President Luiz Inácio Lula da Silva (2003-2010) to President Dilma Rousseff (2011-2016) both from the Partido dos Trabalhadores (Workers' PartyPT). We have not included the controversial transition to President Temer (see Marcondes and Mawdsley 2017). 
Under Lula, Brazilian relations with the global South included a strong emphasis on the language of affect. For example, as his predecessors had done before, Lula acknowledged the important role that Africans, who were forcibly sent to Brazil as slaves, contributed to the formation of the Brazilian nation. Lula recognised a Brazilian moral debt to Africa because of slavery and often mentioned that the provision of NTDC under his presidency was a way of repaying this debt. ${ }^{46}$ At the same time, Lula mobilised affect as a strategy to promote a future of shared prosperity between Brazil and Africa. Speaking as the guest of honor at the African Union Summit in Sirte, Libya, in 2009, Lula stated: "Brazil did not come to Africa to apologize for the colonial past, we want to be true partners in development and cooperation (...) together we can make great things in order to develop our economies". ${ }^{47}$ Within the Brazilian foreign policy rhetoric, the concept of 'non-indifference' was used to justify an increase in Brazilian involvement with humanitarian and development cooperation, including in countries such as Haiti, which had not been on the foreign policy radar in previous administrations. ${ }^{48}$ Lula's mobilization of affective language was often highly personalized - for example, Lula called Libya's Muammar Khadafy a "brother" and a "friend" when he visited, as part of an agenda to expand technical and economic cooperation. ${ }^{49}$

Personal trajectories are clearly invoked in the case of Brazil. When Lula became president in 2003 his interest in foreign affairs was generally unanticipated. Lula was not fluent in foreign languages and his career had developed entirely in Brazil. Although the PT had contacts with other left-wing movements, international issues hadn't featured heavily in the party's agenda. Lula's rise to power nonetheless allowed for a connection between his own personal trajectory of overcoming social exclusion and rising to be the 'face' of the Brazilian left, and Brazil's own trajectory of becoming an emerging economy as part of an economic growth trajectory combined with social inclusion. The social policies expanded by Lula (such as Bolsa Família) started to attract significant international attention as approaches to poverty reduction. Lula was able to personally capitalise on these successes, in part through references to the hardship that he and his family faced during his childhood, first in the Brazilian Northeast and then in the state of São Paulo.

In late 2010, Brazilians elected Dilma Rousseff, a former political prisoner during the country's military dictatorship and a political ally of President Lula, as Brazil's first female president. During the campaign, Rousseff, an economist who served as Ministry 
of Energy (2003-2005) and Chief of Staff to the President (2005-2010) under Lula, was branded as an efficient technocrat and the mastermind behind Brazil's Growth Acceleration Programme (PAC). But while Lula was seen as a charismatic and conciliatory figure, Rousseff was portrayed in the domestic and international media less favourably: "Nicknamed 'Iron Lady', Ms Rousseff's brusque manner and short temper ... have earned her a formidable reputation". ${ }^{50}$ What is relevant for this analysis is that rightly or wrongly - a hostile media and some analysts often explained the downturn in Brazilian development cooperation as the effect of Rouseff's personal lack of interest in overseas issues. While this may have played some role, we should also note the growing problems with the domestic economy, and internal political struggles. One influence of Rousseff's personal trajectory on foreign policy was a stronger emphasis on human rights considerations, particularly during her first mandate (2011-2014), although the record has been ambiguous, with domestic criticism of closer relations with Cuba, Equatorial Guinea and Venezuela. The reality is a more complex one than suggested here, but we observe the extent to which both critics and supporters tell the story with a high degree of focus on the personal characteristics, trajectories and priorities of Lula and Rousseff.

The third element of the framework concerns presidential investment in particular domestic policies, which when taken up internationally may help secure greater legitimation and prestige. This is very evidently the case in Brazil, which actively foregrounds the extension of domestic successes overseas. This has been pursued through bilateral programmes, trilateral programmes (most notably ProSAVANA in Mozambique), and multilaterally. For example, in December 2005, President Lula met with the President of the World Bank, Paul Wolfowitz, who stated: "There is growing evidence that Brazil is reducing poverty and inequality, through a combination of sound economic policies and pro-poor programs, such as Bolsa Família. The Bank is proud to have played a role in supporting such programs". ${ }^{51} \mathrm{~A}$ series of initiatives were developed overseas with a strong connection with national programmes. For example, the emphasis on addressing hunger led to the creation of the Fome Zero (Zero Hunger) programme in 2003 strongly promoted during presidential visits in Africa, Asia and Latin America. Within the Foreign Ministry, a General Coordination for Actions Against Hunger (CGFOME) was created in 2004 to channel Brazil's donations for humanitarian assistance, mostly food, to countries in need. The More Food Programme created within the Ministry of Agrarian Development and designed to support family agriculture in Brazil was 'expanded' to Africa and Latin America via the More Food International 
Programme. Domestic initiatives in the health sector, such as the 'milk-banks' project have also been 'replicated' in African and Latin American countries with the assistance of the Brazilian institutions that developed the programmes at home. ${ }^{52}$

Lula and to a lesser extend Rousseff were able to benefit politically from the sharing of these successful domestic experiences. For example, in 2011, José Graziano, who served as Extraordinary Minister for Food Security under Lula (2003-2004) and who is a key figure associated with the creation of Fome Zero, was elected Director General of the UN's Food and Agriculture Organization (FAO). Graziano's candidacy was supported by African countries with the promise that programmes similar to Fome Zero could be implemented by FAO. The connection between domestic initiatives associated with social policy and Brazilian NTDC continued under Rousseff. A Centre of Excellence Against Hunger (Centro de Excelência Contra Fome) was created in 2011 as part of a joint-action between the Brazilian government and the World Food Programme.

In terms of the fourth element of the framework, Brazil has had a tradition of presidential diplomacy predating Lula/Rousseff. ${ }^{53}$ Active presidential diplomacy under Lula included a wide range of presidential visits overseas and the hosting of foreign leaders in Brazil. Lula was particularly keen to strengthen relations with the global South. During his period in office, Brazil became a member of BRICS and of IBSA, and Lula significantly expanded Brazil's NTDC cooperation. However, Roussef's capacity and desire to implement an active NTDC-oriented presidential diplomacy was undermined by domestic demands deriving from the economic crisis and internal dissatisfaction with the PT-led government, especially due to corruption charges, as well as a perception of the need to refocus Brazilian foreign policy towards more 'traditional markets'.

Finally, the Brazilian case is also illustrative of the weight that political leadership has on NTDC in comparison to a more modest role played by development cooperation institutions. The Brazilian Cooperation Agency (ABC) is not an autonomous agency but a division within the structure of the Foreign Ministry. The reliance on political leadership instead of strong institutional backing is reflected in the fact that although Lula was a vocal supporter of increasing Brazil's role in NTDC, this did not translate into an institutional strengthening of the $\mathrm{ABC}$ or in efforts to provide a refreshed and fit for purpose legal framework for Brazil's involvement in NTDC. ABC's mandate includes coordinating Brazilian development cooperation, but it struggles to do so given over 100 
federal institutions involved in the provision of cooperation. ${ }^{54}$ The emphasis on political leadership rather than institutional backing is also illustrated by the fact that the decision to initiate NTDC projects was often the direct result of presidential visits by either Lula himself or the Foreign Minister. Promises were made by Lula in areas as diverse as biofuels, health and education, which Brazilian institutions would then try to accommodate. President Lula was a strong supporter of the role of the Foreign Ministry and provided his foreign minister with considerable autonomy, which facilitated an increase in the number of incoming diplomats and in the opening of new diplomatic posts, especially in the global South. The situation was different under Rousseff. One interviewee suggested that Rousseff's own trajectory within different ministries means that she was socialized within government sectors that tend to have a negative view of the Foreign Ministry, often identified as inefficient and elitist. ${ }^{55}$ Rousseff's lack of affinity with her first Foreign Minister (who resigned in 2013) is also said to have undermined the continuation of an active foreign policy, compared to Lula's warm relationship with Minister Amorim.

As suggested in our framework, NTDC strategies often foreground a particular reading of a domestic trajectory of overcoming obstacles to development, and achieving poverty reduction and/or economic growth. Thus, efforts to promote NTDC are closely connected to the identity a state aims to project to outside audiences, including, but not limited to, the countries that are the recipients/targets of NTDC. In the specific case of Brazil, President Lula embodied Brazil's (partially) successful domestic experience of economic growth and social inclusion. This transfiguration of the country's experience in the figure of the president proved to be highly successful, especially with audiences in other countries of the global South as well as in certain international organizations that promoted the adaptability of these policies. Nonetheless, this strategy also has its limitations. Since the promotion of Brazilian NTDC was so closely associated with Lula's own charisma and performance, once he was formally out of the office, the hype around NTDC was always likely to lose importance. In combination with a change in political leadership, the more difficult domestic and international circumstances that have contextualised Dilma Rousseff's presidency are the primary drivers of the downturn in Brazilian NTDC, but it is telling that Rousseff's own biography, personal attributes (such as gender) and political dispositions are often invoked to explain this policy shift.

\section{Conclusions}


In this article we have examined how certain loosely shared attributes of NTDC discourse and practice relate to the roles, agency and identities of political leaders. We suggest there are certain characteristic features of NTDC that open up a space for the prominence, performance and role of apex political leaders. The five elements of the framework set out here are the elevation of affect, enabling a resonant and attractive script for leaders in their speeches and presentations of NTDC; the fact that political leaders are themselves personally and politically embedded in shared biographies of development with that of their states; the investment that particular leaders have in legitimizing particular domestic-international development pathways and programmes; the particularly strong role of presidential/prime ministerial diplomacy; and the relative weakness of domestic development cooperation institutions compared to other foreign policy sectors in terms of executive power. As the Brazil example shows, this can provide some explanatory power for periods of contraction as well as expansion of NTDC. We do not wish to overstate this argument - specific histories, contingent circumstances, other actors, political economy and geoeconomic structures are all powerful drivers of NTDC narratives, policies and practices in different places. Even so, preliminary discussions with colleagues and our own observations suggest that the ideas presented here should provide stimulating ways of thinking about political leadership and non-traditional development providers elsewhere. ${ }^{56}$

In writing this, we are also aware that NTDC is highly dynamic and rapidly evolving. Development cooperation infrastructures are growing and deepening in their expertise, experience and capacities. Ordinary people, labourers and companies are becoming more visible drivers and agents of South-South cooperation. The rapidly increasing role for national and regional development banks, and arguably a growing shift in SouthSouth relations, may see the language of affect (around solidarity, shared injustice and so on) replaced by a more pragmatic emphasis on delivering economic growth and mutual benefit. ${ }^{57}$ As NTDC grows and consolidates, the role for political leaders we have described here may change in ways that continue to provide insight into this complex phenomenon. Finally, although we have not pursued a comparative approach in the paper, there are also clearly points of similarity and difference with the (so-called) 'established' donors - longer-standing DAC members. Some characteristics are differently performed and historically located (e.g. charity and humanitarianism rather than solidarity, empathy and justice), while others are not available to contemporary DAC leaders (e.g. the personal identification with a country's development trajectory). By going beyond individual case studies, the aim here has been to explore NTDC in ways 
that provide more analytical purchase on such points of similarity and difference, and some of the patterns observable in what are a diverse and dynamic set of actors.

\section{Bibliography}

Bayly, Susan. Asian Voices in a Post-Colonial Age Vietnam, India and Beyond, Cambridge: Cambridge University Press, 2007.

BBC News, “Dilma Rousseff: Brazil’s Iron Lady", 27 October 2014

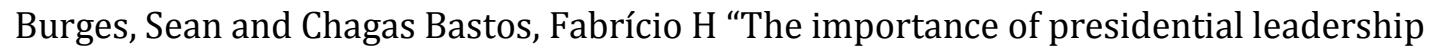
for Brazilian foreign policy" Policy Studies, 38:3 (2017):277-290.

Cho, Chung-un "Officials slam four-river audit: Ruling party calls for countermeasures after audit found project faulty", 18 January 2013, The Korea Herald, http://www.koreaherald.com/view.php?ud=20130118000704 (accessed 11 July 2014).

Chung, Min-uck "Global push for Saemaul Movement in doubt", 4 November 2013, The Korea Times at http://www.koreatimes.co.kr/www/news/nation/2014/08/180_145648.html (accessed 11 July 2014).

Danese, Sérgio F. Diplomacia presidencial, Rio de Janeiro: Topbooks, 1999

DiMoia, John "Mobilizing the Development Narrative: South Korean Developmental Visions for Infrastructure, Domestic and Southeast Asia, 1956-1973", Cambridge University, 21 May 2014, CRASSH seminar, http://www.crassh.cam.ac.uk/events/25573

Douglass, M. “The Saemaul Undong: South Korea's Rural Development Miracle in Historical Perspective", Asia Research Institute Working Paper series No. 197, 2013

Eyben R. and L. Savage. "Emerging and submerging powers: Imagined geographies in the new development partnership at the Busan high fourth level forum", The Journal of Development Studies 49/4 (2013): 457-469.

Eyben, R. "Struggles in Paris: The DAC and the Purposes of Development Aid" European Journal of Development Research 25 (2013): 78-91.

Fejerskov, A.M., E. Lundsgaarde, S. Cold-Ravnkilde "Recasting the 'New Actors in Development' Research Agenda" The European Journal of Development Research, (2017): DOI: 10.1057/s41287-016-0072-1

Han, Seung-Mi. "The New Community Movement: Park Chung Hee and the Making of State Populism in Korea." Pacific Affairs, 77: 1 (2004): 69-89. 
Hermann, Margaret. "Explaining foreign policy behavior using the personal characteristics of political leaders", International Studies Quarterly, 24:1 (1980): 7-46.

Hermann, Margaret, Thomas Preston, Baghat Khorady and Timothy M. Shaw. "Who leads matters: The effects of powerful individuals", International Studies Review, 3:2 (2001): 83-131.

Harsch, Ernest, "Brazil repaying its debt to Africa”, Africa Recovery, v. 17, n. 4, January (2004):4.

Ikenberry, G. John and Jongryn Mo. The Rise of Korean Leadership: Emerging Powers and Liberal International Order, New York: Palgrave Macmillan, 2013

IPEA/ABC. Cooperação Brasileira para o Desenvolvimento Internacional: 2005-2009. Brasília: IPEA, 2010

Joo, Dong-joo, Cha Moon-joong and Kwon Yul et al. The Establishment of the Korean ODA Model, KIET Research Report 2012-622 (1), Seoul: KIET, 2012.

Kalinowski, Thomas and Hyekyung Cho. “Korea's Search for a Global Role between Hard Economic Interests and Soft Power," European Journal of Development Research, 24:2 (2012): 1-19.

Kang, Sung Jin, Hongshik Lee and Bokyeong Park (2011) “Does Korea follow Japan in foreign aid? Relationships between aid and foreign investment", Japan and the World Economy, 23:1, pp 19-27.

Kim, Eun Mee and Jae Eun Lee. "Busan and Beyond: South Korea and the transition from aid effectiveness to development effectiveness", Journal of International Development, 25 (2013): 787-801.

Kim, Hyun. "Excessive budgetary support to Saemaul Undong ODA should stop", press release on 1 November 2013, by MP Kim Hyun, at http://yesokkh.blog.me/, (in Korean).

Kim, Jeong-Su. "The environmental fallout of the Four Major Rivers Project", Hankyoreh News, 3 October 2013, http://www.hani.co.kr/arti/english_edition/e_national/598190.html (accessed 8 October 2014)

Kim, Nam-il. "Parties debate over 'Saemaul Undong' budget”, 22 December, 2013, Hankyoreh, in Korean. http://www.hani.co.kr/arti/politics/assembly/616558.html (accessed 11 July 2014).

Kim, Soyeun. "Bridging Troubled Worlds? An Analysis of the Ethical Case for South Korean Aid," Journal of International Development, 23:6 (2011):802-822. 
Kim, Soyeun and Hanee Kang "Young and dynamic? The curious case of Korea's national level post-2015 process", Journal of International Development, 27:6 (2015): 776-800.

Kim, Sung-Mi. "Critical geopolitics and contemporary development: South Korea's place in the changing landscape of foreign aid", $\mathrm{PhD}$ dissertation, University of Cambridge, 2015

Kim, Sung-Mi. "The domestic politics of international development in South Korea: Stakeholders and competing policy discourses", The Pacific Review, 29:1 (2015):67-91.

Kim, Sung-Mi. "South Korea's middle power diplomacy: changes and challenges", Research Paper, June 2016, London: Chatham House . Accessible at https://www.chathamhouse.org/publication/south-koreas-middle-powerdiplomacy-changes-and-challenges

Kondoh, Hisahiro. "Korea's pathway from recipient to donor: how does Japan matter?" in Jin Sato and Yasutami Shimomura (eds.) The Rise of Asian Donors: Japan's Impact on the Evolution of Emerging Donors, Abingdon and New York: Routledge, 2012

Korea Net. "Korea leads the Green Way" 26 December 2012. http://www.korea.net/NewsFocus/Sci-Tech/view?articleId=104426

Kragelund, P. “Back to BASICs? The rejuvenation of non-traditional donors' development cooperation with Africa" Development and Change 42 (2) (2011): 585-607.

Kwon, Hyuk-ju. “Implications of Korea's Saemaul Undong for International Development Policy: A structural perspective", The Korean Journal of Policy Studies, 25:3 (2010): 87-100.

Mawdsley, Emma, Laura Savage and Sung-Mi Kim. “A ‘Post-Aid World'? Paradigm shift in foreign aid and development cooperation at the 2011 Busan High Level Forum" Geographical Journal 180 (1) (2014): 27-38.

Mawdsley, E. "Development geography 1: Cooperation, competition and convergence between 'North' and 'South'". Progress in Human Geography, first published on August 27 (2015) as doi:10.1177/0309132515601776

Mawdsley, Emma. From Recipients to Donors: Emerging Powers and the Changing Development Landscape, London: Zed Books, 2012

Mawdsley, Emma. "South-South Cooperation in a New Era". Paper presented in Department of Geography, King's College London, March 2017. 
Marcondes, Danilo and Mawdsley, Emma. "South-South in retreat? The transitions from Lula to Rousseff to Temer and Brazilian development cooperation”. International Affairs, forthcoming, 2017.

Mohan, Giles and May Tan-Mullins. "Chinese Migrants in Africa as New Agents of Development? An Analytical Framework", European Journal of Development Research, 21 (2009): 588-605.

Monson, Jamie. Africa's Freedom Railway: How a Chinese Development Project Changed Lives and Livelihoods in Tanzania, Bloomington: Indiana University Press, 2009 Muchapondwa, E. D Nielson, B Parks, AM Strange and M Tierney. “Ground-Truthing' Chinese Development Finance in Africa: Field Evidence from South Africa and Uganda" The Journal of Development Studies, 52 (6) (2016):780-794

Netto, Andrei. "Lula ataca mídia e chama Kadafi de 'amigo e irmão", O Estado de São Paulo, 9 July 2009.

OECD-DAC, “OECD-DAC Peer Review on Korea”, Paris:OECD, 2012.

Prashad, V. The darker nations: A people's history of the Third World. New York: The New Press, 2008

Sato, Jin and Yasutami Shimomura (eds.) The Rise of Asian Donors: Japan's Impact on the Evolution of Emerging Donors, Abingdon and New York: Routledge, 2012

Sidiropoulos, Elizabeth and Thomas Fues. Development cooperation and emerging powers: new partners or old patterns, London: Zed Books, 2012

Soh, Jin-kwang, Gap-jin Chung and Hyung-baek Lim. "Research on the implementation of Saemaul Undong-related ODA model project", a report commissioned by the Ministry of Security and Public Administration, 2011.

Soh, Jin-kwang, Gyeong-soo Lim and Hyung-baek Lim. "Research on ways to enhance effectiveness of Saemaul Undong ODA training programme", a report commissioned by the Ministry of Security and Public Administration, 2012

Sorensen, Jens Stilhoff (ed.) Challenging the Aid Paradigm, Western Currents and Asian Alternatives, Basingstoke: Palgrave MacMillan, 2010.

Svent-Ivany, B. and S. Lightfoot. New Europe's New Development Aid. Routledge, 2015

Taylor, Ian. The Forum on China-Africa Cooperation (FOCAC) New York: Routledge, 2012 van der Merwe, J., I. Taylor, A. Arkhangelskaya (eds.) Emerging Powers in Africa: A New Wave in the Relationship? Palgrave Macmillan, 2016

Vittorini, Simona. "A Nehru-lite Third India-Africa Forum Summit". Presentation at SSAI Panel Discussion, 2015. Available at https://www.soas.ac.uk/south-asiainstitute/events/file108671.pdf

Watson, Iain. "Global Korea: foreign aid and national interests in an age of globalization", 
Contemporary Politics, 17:1 (2011):53-69

Watson, Iain. "South Korea's State-led Soft Power Strategies: Limits on Inter-Korean Relations", Asian Journal of Political Science, 20:3 (2012):304-325.

Watson, Iain. Foreign aid and emerging powers: Asian perspectives on official development assistance, Abingdon and New York: Routledge, 2014a

Watson, Iain. "Green Growth, Neoliberalism and Conflicting Hegemonic Interests: The case of Korea", International Critical Thought, 4:1 (2014a):53-66.

Weinlich, Silke “Emerging powers at the UN: ducking for cover?", Third World Quarterly, 35:10 (2014):1829-1844.

Wiese, I. "Country Study: Saudi Arabia”. GIZ: Regional Programme Cooperation with Arab Donors in the MENA region (CAD)/Working Paper Series, 2016

Weiss, Thomas G. and Adriana Erthal Abdenur "Introduction: emerging powers and the UN -what kind of development partnership?", Third World Quarterly, 35:10 (2014):1749-1758

\section{NOTES}

${ }^{1}$ Mawdsley, From Recipients to Donors; Eyben and Savage, "Emerging and submerging powers"; Svent-Iványi and Lightfoot, New Europe's New Development Aid; Kragelund, "Back to BASICS?"; Wiese "Country study: Saudi Arabia".

2 Fejerskov et al 2017, "Recasting the new actors".

${ }^{3}$ This is, of course, a problematic designation. Many such donors and development partners have been engaged in various forms of development cooperation for decades; while the term inevitably bestows upon western donors the stable identity of being 'traditional' or 'established'. As discussed in detail by Mawdsley (2012) and others, all labels (at this resolution) are imperfect. After much discussion between ourselves and in response to reviewers' comments, we decided to use this term instead of South-South Cooperation. While the reviewers recognized that South Korea shows a series of similarities to Asian donors/partners (e.g. Japan, China) - a provisional and fluid grouping that disconcerts DAC/non-DAC categorization - they were not comfortable with the designation of Southern donor for Korea.

${ }^{4}$ Eyben, "Struggles in Paris"; Weiss and Abdenur "Introduction: emerging powers"; Weinlich, "Emerging powers at the UN".

5 Sorensen, Challenging the aid paradigm; Mawdsley, "Development Geography 1". ${ }^{6}$ van der Merwe et al 2016, Emerging powers in Africa.

${ }^{7}$ For an insightful example, see S Kim and Kang, "Young and Dynamic?".

${ }^{8}$ In 2015 Korea was ranked the 29th richest country in the world according to GDP per capita (adjusted for Purchasing Power Parity). For a list of how different countries rank in terms of wealth as measured by GDP (PPP) see: https://www.gfmag.com/globaldata/economic-data/worlds-richest-and-poorest-countries. For comparison, the UK 
came 27th and Brazil came 79th. If calculated on GDP alone, Brazil would rank 7th and Korea 13th (http://www.worldsrichestcountries.com/)

9 e.g. SM Kim, "The domestic politics of international development".

10 Sorensen, Challenging the aid paradigm; Kang et al., "Does Korea follow Japan";

Kondoh, "Korea's pathway from recipient to donor"; Sato and Shimomura, The Rise of

Asian Donors; Watson, Foreign aid and emerging powers.

11 The data used here have been primarily collected by the different authors from interviews with aid officials, CSOs and researchers, and participant observation in different field sites, including Seoul, Paris, Busan, Brazil and Mozambique.

12 Hermann, "Explaining foreign policy behaviour"; Hermann et al, "Who leads matters".

13 We are referring to the recently published contribution by Burges and Chagas Bastos (2017) which focuses on Brazilian foreign policy.

${ }^{14}$ Muchapondwa et al, "Ground-truthing Chinese development finance".

15 Mawdsley, From Recipients to Donors.

${ }^{16}$ van der Marwe et al 2016, Emerging powers in Africa; Taylor, The Forum on China-

Africa Cooperation.

${ }^{17}$ For example, China's Second Africa Policy Paper 2015. See 'China's second Africa

policy paper' Xinhua, December 4, 2015. Available at:

http://news.xinhuanet.com/english/2015-12/04/c 134886545.htm (Last accessed 14

July 2016)

18 Prashad, The Darker Nations.

19 Bayly, Asian Voices.

${ }^{20}$ Monson, Africa's freedom railway.

${ }^{21}$ Mohan and Tan-Mullins, "Chinese migrants".

22 Taylor, The Forum on China-Africa Cooperation.

${ }^{23}$ Sidiropolous et al, Development Cooperation and emerging powers.

${ }^{24}$ S Kim, "Bridging Troubled Worlds"; Joo et al, The Establishment of the Korean ODA model; Kalinowski and Cho, "Korea's search"; EM Kim and Lee, "Busan and Beyond".

${ }^{25}$ Preliminary data provided at http://www.oecd.org/dac/korea.htm (accessed 26 April 2017)

${ }^{26}$ See 'Seoul Development Consensus for Shared Growth' at

https://www.oecd.org/g20/topics/development/Annex1-Seoul-Development-

Consensus-Shared-Growth.pdf; and 'Busan Partnership for Effective Development

Cooperation' at http://www.oecd.org/development/effectiveness/49650173.pdf

${ }^{27}$ For a critical appraisal of South Korea's middle power diplomacy over recent presidencies, see SM Kim, "South Korea's middle power diplomacy".

${ }^{28}$ President Park's powers were suspended in December 2016 after a legislative

impeachment vote over corruption claims. On 10 March 2017 Korea's Constitutional

Court has formally removed impeached President Park from office.

${ }^{29}$ The speech is available in Korean at:

https://www.youtube.com/watch?v=141zJSFEyYU (accessed 18 September 2014)

${ }^{30} \mathrm{~S}$ Kim and Kang, "Young and Dynamic?".

31 DiMoia, "Mobilizing the Development Narrative."

32 SM Kim, "Critical geopolitics"

33 Mawdsley, Savage and SM Kim, "A post-Aid world".

${ }^{34}$ Ikenberry and Mo, The Rise of Korean Leadership, 9

35 Watson, "Global Korea"; Watson, "South Korea's state-led soft power". The president's personal attendance at the HLF-4 in Busan helped elevate the stature of the conference nationally and internationally, reflecting the president's own intention (interviews with media and government).

${ }^{36}$ Ikenberry and Mo, The Rise of Korea Leadership; Watson, Foreign Aid and Emerging Powers. 
37 Korea Net, "Korea leads".

${ }^{38}$ Cho, "Officials slam"; JS Kim, "The environmental fallout".

${ }^{39} \mathrm{H} \mathrm{Kim}$, "Excessive budgetary support"; NI Kim, "Parties debate”; Chung, "Global push"; SM Kim, "The Domestic Politics".

${ }^{40}$ Soh et al., "Research on the implementation"; Soh et al., "Research on Ways".

${ }^{41}$ Chung, "Global Push"; H Kim, "Excessive budgetary support"; NI Kim, "Parties debate"; SM Kim, "The Domestic Politics".

${ }^{42}$ Han, "The New Community Movement"; Kwon, "Implications of Korea's Saemaul”;

Douglass, "The Saemaul Undong".

43 SM Kim, "The Domestic Politics".

${ }^{44}$ OECD-DAC, "OECD-DAC Peer Review Korea".

${ }^{45}$ S Kim and Kang, "Young and Dynamic".

46 Harsch, "Brazil repaying"

${ }^{47}$ Author's translation from President Lula's speech at the African Union Summit in Sirte (2009). See: 'Futuro do Brasil está ligado à África, diz Lula', G1, 1 July 2009.

48 'Aula inaugural proferida pelo Ministro das Relações Exteriores Embaixador Celso Amorim por ocasião da abertura do curso de Relações Internacionais da Universidade Federal do Rio de Janeiro, 13 de abril de 2009'

${ }^{49}$ Netto, "Lula ataca mídia".

50 BBC News, "Dilma Rousseff".

${ }^{51}$ See: 'World Bank President Paul Wolfowitz Meets Brazil's President Lula' Press

Release No:2006/220/S

Available at:

http://web.worldbank.org/wbsite/external/extaboutus/organization/extpresident/ext pastpresidents/extofficepresident/0,,contentmdk:20758191 menupk:64343642 page pk:51174171 pipk:64258873 thesitepk:1014541,00.html [accessed 10 February 2016]

52 By the same token, Southern partners are stung when these projects fail or encounter contestation, as has happened in the case of ProSAVANA.

53 Danese, Diplomacia presidencial.

${ }^{54}$ IPEA/ABC, Cooperação Brasileira

55 The interviewee also suggested that Rousseff's negative views could help explain her decision to delegate certain competencies of the Foreign Ministry to other ministries such as Treasury and Trade. Interview conducted by Marcondes with Brazilian diplomat serving at the Brazilian Mission to the UN, New York, December 2014.

${ }^{56}$ e.g. Vittorini, "A Nehru-lite Third India-Africa Forum Summit".

${ }^{57}$ Mawdsley, "South-South Cooperation in a New Era". 